\title{
Majdan: Presence and Political Representation in Post-Communist Ukraine
}

\author{
Wim van Meurs and Olga Morozova
}

\section{Introduction: Representation and Presence}

Max Weber distinguished three ideal typical forms of authority and legitimacy. In their crudest form these three - charismatic, traditional, and legal-rational leadership - are typically construed as a sequence of progress toward modern liberal democracy. ${ }^{1}$ More realistically, all individual and institutional authority is grounded in a specific amalgamate of these three types, even in the present era of popular sovereignty, professionalised bureaucracies, and universal suffrage. Having said that, in the twentieth century, authority without a representative claim referring to the people has become next to unthinkable. ${ }^{2}$ Representative claims may differ widely, from representatives who considered themselves the democratically elected political voice of the legitimate interests of a specific part of the electorate, to righteous advocates of a common good, or to populists as mystic spokesmen of "the people" in singular. Similarly, for some, "politics" as the contest of representative claims should take place exclusively in the confines of the democratic institutions of parliament and government. For others, street politics is an acceptable complementary form of representation or even a superior form of democracy. Recent debates on direct democracy set out to re-introduce the polis ideal of the citizen expressing his interests without recourse to representatives or middlemen. ${ }^{3}$

The extraordinary case study of this chapter introduces, among others, citizens who take to the streets, rejecting any form of political representation and leadership, be it populist or not. Their claim is not to represent (part of) the people, but to be the people - a matter of presence instead of representation. The case study exemplifies two key issues of democratic contestation. First, the observation that today the principle of democracy in the widest sense (dimokratia - 'the rule of the common people'), is an integral part of any claim to political authority. Second, the observation that deciding what forms of

1 Weber (2008) 155-208.

2 Saward (2010) 35-56.

3 Setälä (1999); Hollander (2019); Lucardie (2012) 47-6o. 
democracy are acceptable as "legitimate" often defies the very decision-making mechanisms of democracy. The state in question held a long tradition of universal suffrage and democracy as the exclusive prerogative of formal representative institutions (at least de jure), even though political practice amounted to authoritarian one-party rule. Once the ban on alternative forms of democracy and competing types of representative claims had been broken after the fall of the Soviet Union, political debate and action escalated rapidly. Historical references and symbolic loci became instruments in the increasing polarisation, featuring in makeshift expressions of claims to national and political legitimacy and authority. The purpose of this case study is to demonstrate that the political contests of post-communism were not only about political power and more or less sympathetic (from a Western point of view) holders of political office, but also about (un)acceptable forms of democracy and defining the limits of democratic representation.

The present case study concerns Ukraine, a "young democracy" by the standards of Western liberal democracies, although universal suffrage existed under the Soviet Constitution, applicable to the Ukrainian Soviet Republic from 1922 until its independence in 1991. For most of the twentieth century, the Communist Party claimed the status of sole representative of all Ukrainian citizens. Apart from Weber's legal-rational authority, some observers have ascribed "charismatic leadership" to the Communist regime. ${ }^{4}$ In the 199os, by and large politics and representative claims miraculously remained within the confines of the democratic institutions, despite the upheavals of the triple transition to independent statehood, market economy, as well as pluralist democracy and rule of law. ${ }^{5}$ Apparently, the realities of seventy years of oneparty regime notwithstanding, the institutions of democratic representation of independent Ukraine were not but an ephemeral emulation of a Western role model. They derived significant authority from indigenous institutional tradition, Weber's third type.

In sum, in the framework of this volume on repertoires of representation, Ukraine constitutes an interesting (and possibly trendsetting) case of a people's increasing disenchantment, not only with the political establishment, but also with its populist contenders. Conversely, the Ukrainian story also points to the firmness of a well-established tradition of parliamentary representation, even though for most of its recent history, Ukraine had been part of a oneparty system and not a democracy. Arguably, the Majdan protesters have un-

4 Jowitt (1983), especially footnote 4.

5 Kolstø (1995); Melvin (1995); Wittkowsky (1998). 
derestimated the inherent value of this institutional tradition, risking it all by making street politics a legitimate venue for politics.

This study of the discourses and actions of political representation in postcommunist Ukraine focuses on two connected key episodes. The mass protests by Ukrainian-speakers from the western provinces and the capital city triggered by the rigged elections of 2004 constitute the first episode. These protests, the so-called "Orange Revolution," converged on Kyjiv's main square, Majdan Nezaležnosti ('Independence Square'). The second episode began when the pro-Russian candidate Viktor Janukovyč, defeated by the Orange Revolution, eventually became president ten years later. In 2013, he refused to ratify Ukraine's Association Agreement with the European Union, allegedly at Moscow's behest. Oppositional political constituencies gathered on the same square once again that now became known as Euromajdan, a much more protracted and violent confrontation between state authorities and radicalised protest movements (see Figure 9.1).

In view of the extreme ethnic and socio-economic polarisation in the country and a decade of rigged elections and blatant state capture, the relative absence of political violence and street politics prior to 2004 seems more remarkable and more deserving of an explanation than the temporary breakdown of political order in 2004 and again in 2013-2014 during the Majdan protests. The analysis below of the two eruptions of political contestation, however, will also offer explanations for the long and relatively calm intermezzos of institutionalised politics. Both democratic crises concerned contestations of political authority, including representative claims, in parliament as well as on Kyjiv's main square. These crises also concerned controversial forms of political action and their condemnation by political adversaries. We use the term "repertoire" for a coherent set of a legitimising discourse of representation and corresponding forms of political action. More often than not, one party to the conflict argued that both the actions of its opponents and their representative claim were illegitimate. Each party tried to reserve a representative claim for itself and the legitimate forms of action to go with it. The case study will show that these claimants typically failed in upholding exclusive rights to a repertoire. ${ }^{6}$

In 2004, the Pora! movement (Ukrainian: 'time's up!') mobilised citizens not to accept the outcome of the presidential elections as the pro-European liberal candidate Viktor Juščenko publicly accused the candidate form Eastern Ukraine Viktor Janukovyč of election fraud. Pora! argued that since the elections had been manipulated, street protests to ensure that the true winner

6 Tilly (2005); Laclau (1983). 


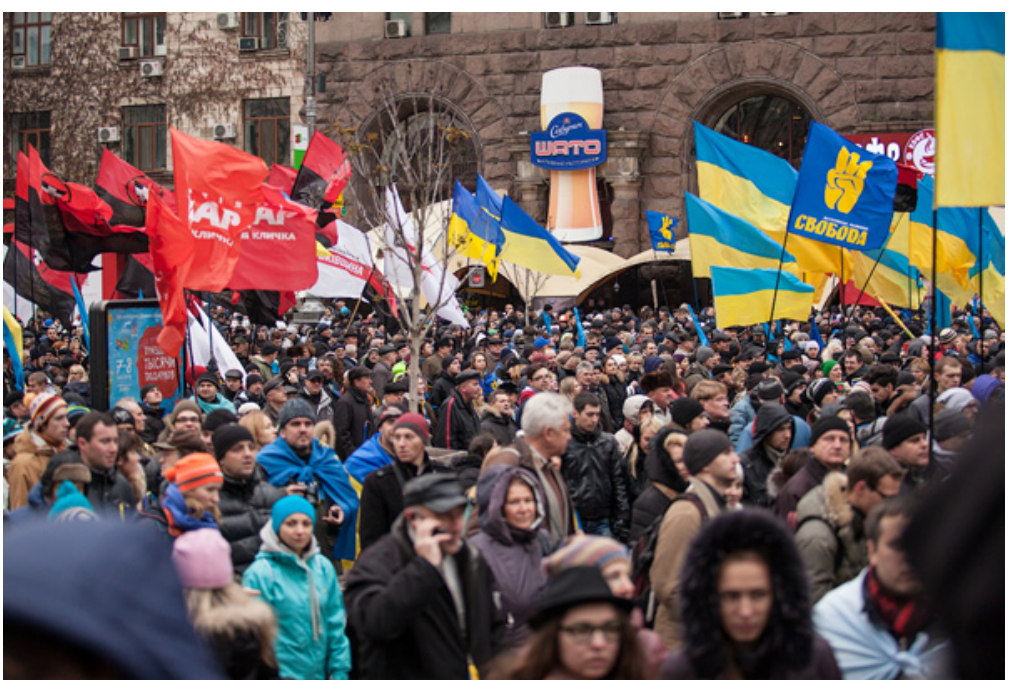

FIGURE 9.1 Euromajdan in Kyiv on 1 December 2013. CC BY 2.0 [accessed online 26.o6.2018: <https://commons.wikimedia.org/wiki/File:Euromaidan_ Kyiv_1-12-13_by_Gnatoush_004.jpg>]. PHOTO: NESSA GNATOUSH.

becomes president were a civic and urgent duty. Once democracy had been lost, it could not be easily restored:

For the foreseeable future, the presidential elections represented their only chance for greater freedom and more rule of law. Russia clarified the alternative with its just-held managed 'elections.' The choice was between democracy or Putin-style authoritarianism. ${ }^{7}$

Evidently, not all protesters were driven by such a principled defence of democratic principles. Many simply blamed president Leonid Kučma and his protégé Janukovyč, for unemployment, crime, poverty, corruption, and despair, rather than supporting Juščenko as victim of electoral fraud. ${ }^{8}$

Russian media in Kyjiv and Moscow had taken a negative stance on the Majdan protests (against the pro-Russian political establishment) in 2004. In 2014, however, they observed a fascist conspiracy instead of a rally of misguided citizens. In January 2014, Argumenty i Fakty, one of the Russia's main weeklies, called the Euromajdan a "brown revolt":

7 Åslund (2006).

8 Tolkačov (2009). 
If any liberal will try to persuade you, that peaceful protesters in Kyjiv are violently protecting the 'European choice,' you can be sure that this person is a liar without honour or conscience. Last week's events have left no illusions: the mob in Kyjiv is attempting a fascist coup. ${ }^{9}$

This study focuses on Majdan as the location of such political contestation. The use, time and again, of the same location for political action adds layer after layer to the symbolic meaning of what is at first sight merely a large open space and traffic junction in the national capital. Apart from the alleged (dis) similarities of the 2004 and 2014 events, older historic events were also selectively added to the bowl in an effort to maximise the symbolic value of the location. Hence, the Majdan has all the qualities associated with a veritable lieu de mémoire. ${ }^{10}$ In addition to the historical diachronic dimension, both the 2014 and 2014 events also abide with synchronous references. The Orange Revolution is often perceived as part of a series of so-called "colour revolutions" in former communist states and Soviet republics between 2000 and 2005. Similarly, 2014 concluded a series of "square revolutions" from Cairo in 2011 to Istanbul in 2013. Not unlike the diachronic dimension, here, too, the question arises what connotations and similarities the organisers of the protests (or their opponents) prefer to emphasise to substantiate their choice of "democratic" repertoire and legitimacy.

In this case, the truth is in the eye of the beholder. In the analysis, the emic perspective from within the social environment is more important than the outsider etic perspective. The revolutions in Belgrade, Kyjiv, and Tbilisi may have been engineered by the same American strategists, ${ }^{11}$ but what really counts here are explicit references and acknowledged role models in the dynamics of political contestation - i.e., the ad-hoc perceptions of the insider rather than the ex-post analysis of the outsider. From a more pragmatic point of view, using the largest square available in the capital for a political mass demonstration seems an obvious choice. Conveniently, the largest square is often also home to some key institutions of political power (albeit not in the case of the Majdan in Kyjiv). ${ }^{12}$ In terms of urban layout, a square in the centre of the capital is bound to have a long history of memorable political events and corresponding national monuments. It is, almost by default, a lieu de mémoire in and by itself.

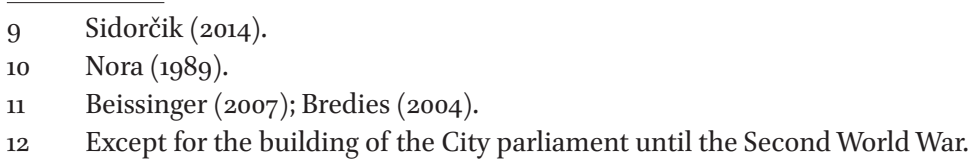


Political scientists have authored most Western studies of either the Majdan events or the colour and square revolutions as generic phenomena. More often than not, they frame the events of 2004 and 2014 as an ethnic conflict between a nationalising state and a minority that happens to be co-nationals of a former imperial power. ${ }^{13}$ And if they do, political scientists typically applaud these political revolutions as proof of the vitality and tenacity of democratic culture among the citizens under authoritarian regimes. Democratisation and national liberation are presented as two sides of the same coin. In the words of a Western sympathiser:

The strength of popular empowerment that had overthrown the leadership of communist parties and their respective political systems was almost forgotten [...]. However, with the turn of the millennium, thousands of citizens returned to the streets and squares, waving banners and flags, protesting against their leadership, and demanding the minimum requirement of democracy: free and fair elections. ${ }^{14}$

Due to its normative justification, these accolades ignore the selective perceptions of the insiders as well as the unwelcome consequences for conventions of political culture and democracy as an institutionalised procedure. Who decides what is "democratic" and what is "undemocratic" behaviour? If pro-Western protesters have the right (or even obligation) to leave the bounds of institutionalised representation for the sake of the people or the nation, how about pro-Russian secessionists and regional constituencies? Therefore, unlike most studies of these revolutions, the analysis below focuses on the meta-level of repertoires of democracy and their proponents, likable or not. Hence, the study incorporates the views from pro-Russian politicians, too - public perceptions and redefined political conventions. ${ }^{15}$

Unsurprisingly, these perspectives often contradict each other. In his memoires Posle Majdana ('After Majdan') former Ukrainian president Leonid Kučma wrote that the Orange Revolution had been (merely) the product of social disappointment and guileless expectations:

People wanted the promised 'Western paradise' to arrive as soon as possible. Many disliked capitalism out of Soviet inertia, but it did not prevent

The debate on the ethnic or socio-economic essence of the polarisation is beyond the scope of this contribution, see: Karklins (1994); Van Meurs (1999); Melvin (1995).

14 Gerlach (2014) 1.

15 Zunneberg and Van Meurs (2014). 
them from living under the motto 'we want a European way of life!' However, under the 'European way of life' they understood only its material appearance, and not the thriftiness, skills to accumulate funds and resources, tireless work and constant learning. ${ }^{16}$

Ten years later, a journalist supportive of the new wave of protests, noticed a laconic banner asking for the understanding of drivers who found Majdan, a key traffic junction, blocked by citizens and barricades: "Please understand us, we are fed up!" Somewhat wilfully, he read this sign to imply that "the people were fed up with judges taking bribes, political repressions, endless corruption, absence of fair elections, 'Soviet'-type economy, and the lowest living standard in Europe."17

On the other side of these barricades, a quite different set of arguments prevailed. In justifying the resistance and separatism of the population of Crimea in 2014, democracy and representation were not the issue:

It so happened that the majority of the Crimean population consists of Russian speakers, Tatars and people of many other nationalities. These people have ancient traditions, history and cultural values of their own. They cannot throw everything at the feet of those, who chose Bandera as their leader and preach Nazism. Our grandfathers fought Nazis and shed their blood in order for us not to put their memory to shame. ${ }^{18}$

In sum, no lack of contentious historical and representative claims here to justify political mobilisation outside of the democratic institutions or a clampdown on street politics by the political establishment.

\section{The Majdan in 2004 and 2014}

The Constitution of Ukraine has been adopted in 1996 under the second president Leonid Kučma. This document cemented Ukraine's sovereignty and provided much-needed legitimacy. Ever since the fall of the Soviet Union and Ukrainian independence in 1991, the main challenge for Ukraine has been to preserve its statehood despite being heavily dependent upon Russia for energy resources and exports. Backed by oligarchic elites from southern and eastern

\footnotetext{
$16 \operatorname{Kučma~(2007)~} 24$.

17 Stražnyj (2016) 69.

18 Anon. (2014).
} 
Ukraine, Kučma was interested in free trade with Russia, but remained cautious about entering any agreements, which would require Ukraine to commit to the cis integration.

During Kučma's second term in office (1999-2005), oligarchs and their political parties became even more influential in Ukraine and the democratic "orange" coalition, supported by the socialists, found itself in the opposition. The oligarchs' supporters were mainly found among the Russian-speaking population of the industrial cities of Eastern Ukraine - which were especially reliant on Russia for cheap energy and a market for their products. Every once in a while, Russia played the "Crimean card" to put pressure on Kyiv. The peninsula had been a "gift" to the Ukrainian Soviet Republic in 1954 at the occasion of the three hundredth anniversary of the first "alliance" between Russia and Ukraine. However, as Ukraine gained independence Russia could never make peace with having to part with a region of such strategic significance.

Once the richest Soviet republic and by area the largest state in Europe with more than 40 million inhabitants, Ukraine found itself stuck between the EU and Russia. It has always been half-hearted about the Russian-led regional integration projects like the Commonwealth of Independent States (CIS) or Eurasian Economic Union (EEU), while for Russia getting Ukraine on board with these projects has been a key strategic objective for over a decade. At the same time, Ukraine also struggled to make a commitment to the EU integration without a membership perspective and it was not until 2014 that the scales tipped in favour of westward integration and the unsolved Crimea issue finally backfired.

Along this road, the presidential elections of 2004 and the subsequent Orange Revolution have served as an important turning point. They were heralded as a major democratic breakthrough and definitely pointed in the European direction. The "orange" leaders Viktor Juščenko and Julia Tymošenko accused Viktor Janukovyč, the key contender from eastern Ukraine favoured by Kučma, of election fraud. The rigged elections' results gave Janukovyč a one per cent margin over Juščenko and immediately, thousands gathered on the Majdan in peaceful protest. These protests grew into organised rallies on Kyjiv's main square and a series of sit-ins, demonstrations, and strikes all over the country lasting for over a month. The largest demonstration with half a million participants took place on November 23, 2004 on the Majdan in Kyiv. Eventually, Ukraine's Supreme Court ordered a revote. Despite its eventual electoral victory, the revolution also demonstrated the extent to which Ukraine was sharply divided in a pro-Russian "East" and a pro-European "West." Juščenko 
gathered up to 93 per cent of the vote in some western provinces, whereas his opponent won in the easternmost provinces by similar margins. ${ }^{19}$

Upon becoming president, Juščenko started negotiations on a new EUUkraine agreement. On the EU's part, this decision was taken in the context of the European Neighbourhood Policy (ENP), inspired by the Orange Revolution. It was welcomed in Ukraine as a promise of future membership. The negotiations on what later came to be known as the Association Agreement (AA) started in 2007, followed by the negotiations on its economic part, the Deep and Comprehensive Free Trade Area (DCFTA), after Ukraine's accession to the WTO in 2008.

However, the Juščenko presidency resulted in a disillusion and Viktor Janukovyč came back with a vengeance, using the economic crisis of 2008 as a platform to become the next president. Upon becoming president, he sent Tymošenko to prison on propped-up charges and her confederates came to the fore as the new opposition leaders. During Janukovyč's presidency, the country had definitely started to lean more towards Russia, albeit inconsistently. Even though EU integration remained a strategic objective for Ukraine, the longterm perspective Brussels offered did not provide a solution for the most pressing issues of economic malaise and energy security. Nevertheless, the expectations for the Association Agreement were high among the people and had great symbolic value. Tymošenko's release was one of the EU's conditions for signing this agreement, but Janukovyč refused to comply. Instead, he chose a tough line, suppressing his domestic critics and ignoring international pressure. Eventually, Janukovyč was ready to sign the EU Association Agreement in November 2013. At that very moment, Putin offered him a favourable cis Free Trade Agreement deal involving loans and cheap gas, and the Ukrainian president made a U-turn in Vilnius, refusing to ratify the EU document.

The Euromajdan, a peaceful demonstration in support of the agreement, had actually started before, but radicalised when news of the president's second thoughts spread. From this moment on, the word majdan no longer referred to Independence Square in Kyjiv, but stood for the whole revolutionary movement, its attributes, symbols, and traditions. In January 2014 three protesters were killed by snipers, the first casualties in a mass demonstration in post-Soviet Ukraine. The violence started spiralling out of hand quickly, marking the breakdown of the already weakened political system and a few days later, president Janukovyč fled the country. Hoping to regain power, he instigated separatist uprisings in his strongholds in the east of Ukraine. A month 
later the Crimean Peninsula had been annexed by Russia and military conflict in the eastern provinces of Luhansk and Donetsk had started.

The victorious protesters from Euromajdan forced the Rada (Ukraine's national parliament) to install a transitional government and organise new presidential elections. In May 2014, Petro Porošenko, a prominent businessman who used to be close to Juščenko, was elected. He immediately renewed the Association Agreement negotiations and although the ratification process is almost complete by now, people's trust in the government has reached a new low. Moreover, it has become clear that the hybrid war in the Donbas region is not going to end any time soon and is de facto becoming another frozen conflict, providing the Kremlin with additional leverage over Kyjiv. ${ }^{20}$

Both in the Orange Revolution and in the Euromajdan a decade later, the protesters and the political establishment had ample choices of political repertoires to claim a voice in Ukrainian politics, with unforeseeable consequences. The fact that both these political clashes were associated with similar contemporaneous events elsewhere in the world further complicated the war of words and action on the Majdan. The next paragraph takes a closer look at these synchronous connections as an alternative to the more common diachronic references to preceding events and claims.

\section{Synchronous Repertoires of Civil Mobilisation}

In 2000, Otpor! ('Resistance'), a loose network of students all over Serbia ignited mass protests against fraudulent presidential elections and forced authoritarian leader Slobodan Milošević to acknowledge electoral defeat and resign. It succeeded, where oppositional political parties had failed time and again in the 1990s. The key to this success of Otpor! was non-violent demonstrations by youth and in particular students who were accepted by the population at large as genuine and a-political in their concerns. Their spokesmen, trained by Western strategists and spin-doctors, moreover, were the first to use world media as a political weapon systematically - to mobilise their fellow-countrymen, to spread their message and to unmask the repressive regime. ${ }^{21}$ In retrospect, it became known that expertise and resources from us agencies and democracypromoting NGOs had contributed substantially to Otpor!'s victory. ${ }^{22}$

20 Kuzio (2016); Samokhvalov (2015); Stepanenko (2015).

$21 \quad$ Richard Sakwa uses the term "informational warfare," Sakwa (2014) ix.

22 Beissinger (2007); Thumann (2004) 
Otpor! quickly became a role model for urban youth in other authoritarian or "hybrid" (rather than outright dictatorial) states. Allegedly, us advisors and Otpor! activists played a part in the so-called Rose Revolution in Georgia two years later. Here, too, a civil youth movement, Kmara, fuelled protests against electoral fraud and toppled the regime of former Soviet foreign minister Eduard Ševardnadze without resorting to violence, but with the aid of Western public opinion and advisors. The so-called Tulip Revolution in Kyrgyzstan and the Cedar Revolution in Lebanon shared some of these characteristics and, like several other national protest movements, they tried to claim this pedigree (Belgrade and Kyjiv) and the promise of success it held, albeit without success. $^{23}$

At the time, geographic proximity and strategic weight guaranteed the 2004 Orange Revolution in Ukraine the undivided attention of politicians and the media, both in the West and in Russia. The Majdan protests of 2004, too, have been led by a non-violent civil movement Pora! which consisted primarily of students who gathered in reaction to the repression, cronyism, and corruption during the run-off of the presidential elections. The similar names of the students' movements, the same clever media campaigns, and non-violent mobilisation strategies in reaction to fraudulent elections made the Orange Revolution part and parcel of a wider phenomenon of colour revolutions.

Although the common origins of the media campaigns and the advisors behind the scenes were proven only later, the Kučma/Janukovyč regime eagerly accused Western governments of instigating and financing unrest and discord in Ukraine. Juščenko, Tymošenko, and the Pora! movement took great care to present their protests as pro-Western and yet "spontaneous" and authentic. ${ }^{24}$ The generic term "colour revolution" was coined in retrospect only, when protesters in Georgia and Kyrgyzstan explicitly stated their indebtedness to the Orange Revolution. By that time, the term became not only an analytical category, but also a political agenda, a wake-up call to civil opposition in other authoritarian states. Reportedly, the rulers in neighbouring Moldova replaced the (orange) uniforms of traffic wardens as a precaution. ${ }^{25}$

Correspondingly, newspapers and other media loyal to the regime claimed to have uncovered shady connections between the protesters and Western secret services (and with some justification). Drawing a parallel to Belgrade in 2000 and Otpor! might have backfired. Former Yugoslav president Milošević, now a detainee in The Hague, might be embraced as part of a Slavic brother-

\footnotetext{
23 Beissinger (2007); Levitsky (2010).

24 Kuzio (1997).

25 Negru (2010).
} 
hood by the political establishment in Kyjiv, but his dictatorial regime and his fall in particular suggested unwelcome parallels more powerful than allegations of anti-national allegiances on the part of the revolutionaries.

It was hard not to notice a parallel between the Serbian Otpor! and Ukrainian Pora!, as Pora! activists, just like Kmara protesters in Georgia, were building on the Belgrade experience and had indeed been trained by the same people. During the Orange Revolution, this connection was not necessarily perceived as negative, as the 2004 Majdan itself has been meticulously organised. While the organisers took pride in the spontaneous and genuine support of the citizens, they also admitted that it took a well-planned strategy to outmanoeuvre the political nomenclature. According to one of the organisers, Vladimir Filenko, back then

there were no spontaneous gatherings, but thoroughly planned actions. Maybe, precisely because everything has been consistently prepared beforehand, no-one died during the Orange Majdan. Yes, we are very proud of it. We have foreseen different options and courses of action, depending on the government's reaction. We have written A and B plans, sometimes even $\mathrm{C}$ for each operation. ${ }^{26}$

These connections to Belgrade resurfaced ten years later, albeit they were less obvious then:

Currently, Pora!, after having been transformed into unsuccessful political parties, has become a brand, which is not being used anymore. However, on 1st of December in the Kyjiv streets one could see a bulldozer, which looked exactly like the one that 'attacked' the government building in Belgrade on the $5^{\text {th }}$ of October 2000, when Milošević's regime was overthrown. So, in one way or another, Otpor! is present in Kyjiv once again, after it has already made Ukrainians 'happy' 10 years ago. ${ }^{27}$

References to Otpor! and its democratic victory in Belgrade four years before were quite rare in the partisan media as well as on the banners and pamphlets of the protesters. Implicitly, their task of reversing electoral fraud by a wellentrenched regime backed by Moscow in a strategically important major European state seemed much more daunting than toppling an isolated dictator in

$26 \quad$ Filenko (2014).

27 Džurkovič (2014). 
Serbia, six times smaller than Ukraine. Pro-regime media indeed hinted at a Western conspiracy instigating "revolutions" in Russia's "near abroad":

Revolutions toppled the regimes loyal to Russia one after another. Could it be a coincidence? Maybe someone has created an effective system of constant revolutions - 'rose,' 'orange,' 'singing' and others, and this someone completely disregards the laws of these countries? ${ }^{28}$

This quote labels the revolutions as alien and in violation of national law and order.

A decade after the Orange Revolution, the renewed protest on the Majdan had a distinctly different objective - the forced abdication of the democratically elected head of state rather than a re-run of presidential elections because of fraud. Arguably, the Ukrainian protests again fitted into a wider pattern of square revolutions. The Arab Spring of 2011-2013 set the stage with long-time dictators swept from office in Cairo, Tunis, Sana'a, and Tripoli. Even in Russia, Putin's re-election triggered civil protests on Bolotnaja Square, put down by the militia. The Majdan-like Tahrir Square in Cairo and Taksim Square with Gezi Park in Istanbul in 2013-2014 became symbolic hotbeds of civic activism and anti-politics to have popular accountability restored. During the Euromajdan, the Association Agreement with the EU was more of a catalyst than the sole bone of contention. Most of the protesters simply abhorred the rampant corruption and misgovernment of the political and economic establishment. $^{29}$

This time, the other square revolutions predated Euromajdan. Strategically, role model acknowledgement was less problematic, as these revolutions had not been stage-managed by American or European agencies. The fact that these revolutions all occurred outside of the circle of former Soviet republics lessened the appeal of such references. Strong personal networks existed among democratic opposition in former Soviet republics and once in power they solidarized in their attempts to ward off Russian encroachments, using a combination of energy resources, economic sanctions, Russian minorities, military threats, and political pressure to maintain or regain a degree of control over these newly independent states. From a Ukrainian perspective, Cairo and Istanbul were quite alien contexts, despite the invigorating appeal of seeing a crowd of citizens succeed in standing up for its rights and interests.

28 Zuev (2009).

29 Onuch (2014). 
To some extent, the Western advisors and sponsors of the colour revolutions (more than the square revolutions) constituted a veritable and tangible transnational connection between these events and groups. Role model strategies and the encouragement of successful examples constitute more implicit connections. These connections are construed discursively. Framing by local and international media and political actors is decisive. Social media and twitter tags had multiplied the force and immediacy of international public opinion in a timespan of ten years. The very term "colour revolution" and the in- or exclusion of a specific country from the caucus of square revolutions constitutes framing and has a political impact. ${ }^{30}$

The next section deals with the much more common phenomenon of political entrepreneurs claiming historical pedigree to prove their legitimacy or, conversely, linking the opponent's actions to a negative predecessor in order to discredit the movement. From this diachronic perspective, too, the Majdan is again littered with positive and negative references to (recent) history and discursive weapons.

\section{Diachronic Repertoires of National Resilience}

When the demonstrators occupied the Majdan in 2004 and again in 2014, their astute media campaigners made the most of the location - not only the wide camera shots of hundreds of thousands of citizens and thousands of Ukrainian flags and orange banners taken from high-rise buildings lining the square, but also the symbolic ammunition the location provided. Conversely, the adversaries facing each other on Majdan also used negative imagery and historical associations to discredit and disqualify one another in the eyes of omnipresent world public opinion and local constituencies. No scriptwriter could have come up with a better setting for iconic images and dramatic shots heavy with meaning: top-down shots of the crowd and its blue-yellow and orange markers, menacing riot police in black combat gear, protesters clinging to the Independence Monument, the Majdan at night set ablaze by bonfires.

Sometimes, the high drama of images produces incidental but meaningful associations, noticed by history-savvy Western observers and astute local propagandists. The image of citizens scaling the monument and waving flags and banners against a backdrop of buildings hidden by smoke became almost as iconic as the tag \#euromaidan. Whether it had been stage-managed or not, but the reference to Eugène Delacroix' famous Louvre painting "Liberty Leading 
the People," an homage to the July Revolution of 1830 in France that toppled the restauration regime of Charles $\mathrm{X}$ is there. No written plea on the nexus between the nation, liberty, and the power of the people could have been more powerful.

In 2004, Juščenko and Tymošenko contrasted their own liberal-democratic and Ukrainian-national views to the political establishment's pseudo-democracy and subservience to Russian interests. Inevitably, they claimed to be the sole representatives of Ukrainian national interests. Hence, the very name of the location Majdan Nezaležnosti or 'Independence Square' was a first asset. The square, dating back to the nineteenth century, had been renamed (previously: Square of the October Revolution) in 1991 to commemorate the regaining of national statehood with the dissolution of the Soviet Federation. The protesters hoped to complete independence with the election of a truly democratic and independent president. The word majdan for 'square' in Ukrainian is of Arab rather than Slavic origin (compare: Taksim Square in Turkish: Taksim Meydanı) and primarily emphasises cultural distance to the Russian synonym ploščad' (or plošča in Ukrainian). The alternative name suggested in 1991, Plošča Svobody ('Liberty Square') would have chosen the Slavic synonym for "square" and liberty would have referred to both independent statehood of 1991 and the Russian Revolutions of 1917.

More importantly, the square features several important monuments, one to the legendary founders of Kyjiv, one to the folklore hero Cossack Mamaj, and one to the city's guardian saint, Archangel Michael. ${ }^{31}$ All three constitute symbolic, rather than factual-historical references, to a glorious national past. Conveniently, the monument to the October Revolution had been removed. The domineering monument, however, is the victory column erected in 2001 to commemorate a decade of independence, a 200-foot-high column. The column is a quite eclectic brass statue of a young woman in national costume with a viburnum branch in her raised hands, allegorically representing Ukraine.

After the monument of the October Revolution had been removed from the Majdan in 1991, the Lenin monument on nearby Ševčenko Boulevard was considered the main communist symbol left in Ukraine. Since the early 2010s, the government began gradually removing Lenin monuments from the city squares all over Ukraine. ${ }^{32}$ However, the unauthorised removal of the Ukraine's most revered statue of Lenin during the early stage of Majdan at the end of 2013 by the protesters has been highly controversial.

31 Anon. (2012); Anon. (2007).

32 Anon. (2013b). 
The prime minister's office accused the protesters of destroying a monument from the Unesco World Heritage list, an act of barbarism comparable only to the demolition of an ancient Buddha statue in Afghanistan by the Taliban. According to the Kyjiv City Administration this act of vandalism had "nothing to do with democracy." Nevertheless, the demolition of the Lenin monument has been criticised not only by the opponents of the Euromajdan. Ruslana, a famous Ukrainian Eurovision winner and an ardent supporter of both Majdans, wrote:

While our peaceful initiative requires mutual solidarity and unity around Majdan and peaceful protests for the dismissal of the criminal government, destroying monuments and calling for aggression is absolutely counterproductive. It sets us further back from Euro-integration and humane society. ${ }^{33}$

At the same time, liberal Russian politician and human-rights activist Valerija Novodvorskaja welcomed the demolition and said that monuments of this kind have no place in a civilised city: "The demolition of the Lenin monument cannot be considered a provocation, just like a Hitler monument's removal cannot. The very fact of its existence is a crime. Such monuments can only be present where criminals and villains rule." 34

For the campaign managers of 2004, recent memory offered useful associations of the ongoing anti-Kučma and anti-Janukovyč demonstrations to the large-scale protests of the 1990 student Revolution on Granite and the 20002001 "Ukraine without Kučma" demonstrations. The "granite" student strike movement compelled Ukraine's Communist leadership to pursue first sovereignty and next independence. The 2000-2001 demonstrations on the Majdan were a prefiguration of the Orange Revolution, demanding the resignation of President Leonid Kučma, but this early rebellion had been easily suppressed by the security forces. In 1994, a contest had been initiated for the best independence monument. Fearing another round of protests and encampments during the upcoming elections, the government in 2001 hurriedly picked a winner. The square was immediately enclosed by building fences under the pretext of beginning construction work. The demonstrations that took place, nevertheless, became known as "Ukraine without Kučma." Moreover, the current government, brought to power by Euromajdan, announced a "Territory of Dignity" tender to turn the Independence Square from an open space into a 
park zone planted with trees. Thus, as much as the materiality of the square has shaped the protest movement, both protesters and vested powers have also set about to redesign the square to suit their purposes and projections. ${ }^{35}$

Apart from obviously and easily steering clear of all Soviet and Russian references, in 2004 the symbolism of the Majdan was like wax in the hands of the pro-independence campaigners. A decade later, the same legendary and heroic references embodied by the monuments were still valuable. The Euromajdan pledged adherence to the same national historic and cultural traditions.

When asked whether the Ukrainian "Majdans" are connected with each other, one of the Orange Revolution organisers, Vladimir Filenko, resolutely answered that he sees them as a continuation of the struggle for independence:

Speaking of the most recent Ukrainian history, they all were continuing the Revolution on Granite, but if we consider the more distant past, the Majdans are a prolongation of the Hetmanate [an early-modern Cossack state in central and north -eastern Ukraine, OM] and the Cossack legacy. During the twentieth century alone we have had five attempts to restore Ukrainian independence [Filenko refers to the short -lived state-entities of the Ukrainian People's Republic of 1917, the West Ukrainian People's Republic of 1919, the Carpatho-Ukraine of 1938-39 as well as the declarations of independence of 1941 and 1991, OM] Actually, the word majdan is of Turkic origin. As we all know, we share common history with Turks and Tatars, so we borrowed this one from them too. Generally speaking, Majdan is not just a modern Ukrainian phenomenon, but is relevant to the global history as a whole. This notion emerged long before the Orange Revolution and I am happy to have been one of those, who succeeded in bringing it back to Ukraine. ${ }^{36}$

Just like two other prominent Majdan organisers, Taras Steckiv and Roman Bezsmertnyj, Filenko is a historian by education and saw the Majdan [as a generic and timeless locus of national resilience, $\mathrm{OM}$ ] as a "manifestation of direct democracy." 37

In sum, the Majdan revolutions in Ukraine have been explicitly framed in terms of national history and tradition. Indeed, this tradition refers back to the Cossacks, who used to hold meetings, where everyone from the crowd would

35 Anon. (2015).

$36 \quad$ Filenko (2014).

37 Ibid. 
give his opinion and the decisions would be taken by voting or consensus. These meetings gave the Ukrainian parliament its name - Rada, and were held on the central squares - majdans. Hence Filenko's association with direct democracy. Supposedly, this form of government was widespread on a local level during the Hetmanate of the second half of the seventeenth and the beginning of the eighteenth century. This is also a radical "ideal type" of democracy without representation the most vigorous Majdan protesters championed when things were moving their way in 2014.

Thus, for Euromajdan, historical antecedents were much more complicated than for the 2004 protesters. Oddly enough, the Orange Revolution itself was the elephant in the room here. The high hopes placed in President Juščenko and Prime Minister Tymošenko in 2004 had quickly ended in utter and bitter disappointment. Tymošenko's terms of office $(2005,2007-2010)$ became synonymous to corruption, stalled reforms and malpractice. The next presidential elections in 2010, deemed relatively free and fair, had witnessed restauration with Janukovyč defeating Tymošenko.

Tellingly, in Ukraine, Euromajdan of 2014 is often referred to as Revoljucija Hidnosti ('Revolution of Dignity'), in contrast to the politicking of $2004 \cdot{ }^{38}$ This time, the protest movement was characterised by general distrust of all politicians and politicking, including the former heroes of the Orange Revolution. (Juščenko had left politics after his one term of office as president.) When in 2014 Tymošenko was released from prison on Brussels' intercession (convicted to a sentence of seven years for embezzlement and abuse of power), the protesters at the Majdan refused to welcome her as martyr, nor did they recognise her as their leader. Immediately upon release she hurried to the Majdan and delivered a speech in an attempt to take the lead over the revolution that was on its peak. The crowd, however, had mixed feelings about her appearance: some were praising her, while others shouted that they had no trust, referring both to her and the political class as a whole. ${ }^{39}$ Tymošenko also cautiously hinted that she could become a "guarantor of the Constitution," if the people wished so. A few ardent supporters shouted "Tymošenko for president!", but the crowd failed to pick up on this slogan. People were whispering to one another that they were not standing on the Majdan to make her president, but for real changes for the better in their lives. ${ }^{40}$ In a quite unique move, having learned the lesson of 2004, the protesters this time refused to be "led" or

\footnotetext{
$38 \quad$ Sakwa (2014) 81 .

39 Anon. (2014b).

40 Anon. (2014c).
} 
"represented," returning to the romantic ideal of popular sovereignty imagined as a coherent sequence from the Cossack Hetmanate to the Ukrainian Revolution of 1917 and the final milestone in 1991.

Despite the apparent similarities, this Revolution of Dignity was presented as fundamentally different from the Orange Revolution precisely because of its spontaneous character and absence of distinct leadership. The utter disenchantment with any forms of political leadership since 2004 led to a reversal of values a decade later: spontaneity instead of strategic planning; aggrieved citizens asserting themselves instead of defending a disenfranchised political representative.

As one Ukrainian observer noted in retrospect:

Janukovyčs boorish behaviour regarding the Association Agreement has offended people more than any events since 2004. Because of the mass character and enthusiasm around these actions, they are even being compared to the Majdan of 2004. Contrary to the popular opinion about the spontaneity of the Orange Revolution, the 2004 Majdan had been thoroughly prepared. On the opposite, the organised actions during the Euromajdan were quite fragmentary. It can also be explained by the difference in circumstances - there are no presidential elections right now. In the course of the past nine years, many Ukrainians have become disappointed about the possibility of any changes and do not trust the politicians. $^{41}$

Another sympathetic commentator concluded that revolutions were typically led by charismatic leaders, but not so in the case of Euromajdan:

There were only coordinators: opposition deputies were 'responsible' for the parliament, ex-ministers of Foreign Affairs Boris Tarasjuk and Petro Porošenko - for the relations with international organisations, the campsite commandant Andrij Parubij - for forage and defence, Samooborona (Self Defence) captains - for security, stage managers - for speeches and performances. ${ }^{42}$

In sum, the initiators of the second Majdan went to great lengths to dissuade any associations with the first one. Arguably, they even built their very reputation on being fundamentally different, as one of its participants has noted:

\footnotetext{
41 Šmajda (2013).

42 Stražnyj (2016) 229.
} 
All in all, from the very beginning only place and time united these seemingly similar events. Both Majdans started in the same place - the Independence Square, and the same time - the 21st of November. However, during the Orange Majdan of 2004 with its light-hearted festive spirit, the most important thing was that people were sure the government would not start killing them. Back then, we naively shouted 'Police is with the people!' and the policemen, shyly smiling, stayed neutral. We chanted 'East and West are together!' - and it seemed as if there was no disagreement among us, nor could there ever be any. We called for Juščenko and thought that replacing Kučma with him would be enough. ${ }^{43}$

The new leaders of the pro-European protests were clearly professional politicians with diverging agendas and beliefs, sharing only the rejection of a future for Ukraine as Russian dependence. Only the party UDAR and its leader, former boxing champion Vitalij Klyčko, could claim some charismatic authority and popularity (locally and in the West). Not so for Tymošenko's conservative AllUkrainian Union "Fatherland" and certainly not for the extremist and violent Right Sector led by the ill-reputed Dmytro Jaroš. The Moscow-supported separatism in eastern Ukraine and the annexation of Crimea created a state of national emergency in Kyjiv. Oligarch and entrepreneur Petro Porošenko became president and a national figure of sorts, but by no means the unblemished charismatic hero entrusted with the nation's future president Juščenko had been in 2004.

Both for domestic audiences and international public opinion, pro-Russian media in Ukraine and Moscow-based outlets made every effort to reduce the image of the protest movement and its leaders to the violent, extreme-nationalist, and xenophobic groups in the heterogeneous coalition of the Euromajdan. The Right Sector and excesses during the protests offered ample targets for such counterattacks. Apart from images of masked protesters wielding heavy weapons, the ubiquitous framing was "fascism." The new "illegitimate" regime was effectively and consistently labelled as "fascist" (rather than "undemocratic"). Since Soviet times, "fascist" had become a strong generic derogative term separated from any historical reference or comparison. In the secessionist action in eastern Ukraine and Crimea, liberation of the local (Russian-speaking) population from the new "fascist" government in Kyjiv was a strong legitimising and mobilising discourse.

In the context of Euromajdan, both sides remembered and instrumentalised the Ukrainian militant nationalist struggle for independence. However,

43 Anon. (2016c). 


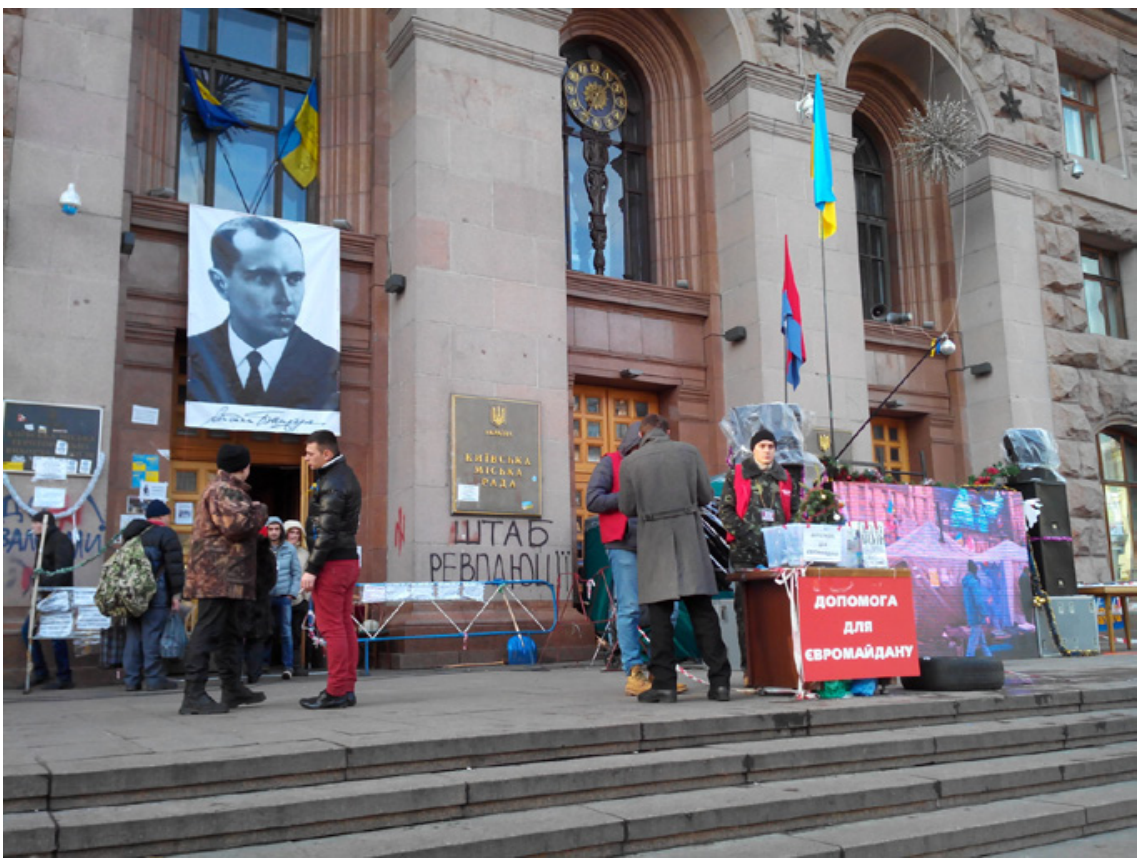

FIGURE 9.2 The headquarters of Euromajdan in January 2014, a prominent portrait of Stepan Bandera at the front entrance. [CC BY-SA 2.0, accessed online 26.06.2018: <https:// commons.wikimedia.org/wiki/File:Headquarters_of_the_Euromaidan_revolution. jpg> ].

while Ukrainians emphasised the anti-Bolshevik Ukrainian Revolution of 1917, Russians focused almost exclusively on Ukrainian Insurgent Army (UPA) that had fought against the Soviet regime during the Second World War with utter ruthlessness and ended up as allies of Nazi-Germany. In the same vein, Stepan Bandera, a Ukrainian nationalist leader from western Ukraine in the interwar period, was associated with Euromajdan by its opponents. The association involved racist nationalism, atrocities, treason, and collaboration with fascism. ${ }^{44}$ His Organisation of Ukrainian Nationalists (oun) had collaborated with NaziGermany in the war to free Ukraine from Soviet hegemony.

When accused of holding elections at gunpoint in his self-proclaimed Luhansk People's Republic, the separatists' leader Igor Plotnickij retaliated: "Porošenko's theory [...] is a blatant lie. It is just low. Porošenko himself came to power as a result of the violent pro-Bandera February coup in Kyjiv, which

44 Riabchuk (2016); Plokhy (2010). 
was anti-constitutional and bloody." 45 This type of negative framing appealed to many Ukrainians' fear of civil war, disorder and economic devastation. It also casted doubt on the credentials of Euromajdan as a whole in the eyes of Western public opinion that preferred to associate Euromajdan to national liberation and democracy, the image of Delacroix. Undeniably, the UPA featured regularly on Majdan and so did images of Bandera and oun (see Figure 9.2). For part of the protesters these references constituted the strongest possible appeal to national resilience and hard choices for the sake of national sovereignty. In 2010, President Juščenko had awarded Bandera the title of Hero of Ukraine, a controversial decision immediately revoked by his pro-Russian successor and condemned by the European Parliament, which would backfire four years later when the Euromajdan broke out. The flip side of Ukrainian nationalism has become the main theme in Russian propaganda against Ukraine. $^{46}$

\section{The Third Majdan of Confutation}

At the third anniversary of the Euromajdan, political scientist Oleg Saakjan observed:

Politicians will not come out onto Majdan, because Majdan continued its life as the Revolution of Dignity in the work of volunteers, civil activists, experts and other people who are working to transform the country. For the politicians, the Majdan ended, because it brought them to power and therefore fulfilled its function. ${ }^{47}$

At the same time in late 2016, the call for a "third Majdan" appeared in (social) media. Informed by the above analysis of the Majdan's synchronous and diachronic connotations of representation and legitimacy, the term itself gives pause. Firstly, "third Majdan" suggests a sequence and continuity that the protesters of the second Majdan vehemently denied. The first Majdan had defended one half of the political elite against the other within the confines of representative democracy or defended these very rules of the game of representative democracy against the infringement of rigged elections. The second had moved to a new level of "revolution," ousting a democratically elected

45 Anon. (2017); quoted from: Bedritskiy (2015) 187.

46 Sakwa (2014) 20.

47 Anon. (2016b). 
president because of the political choices he made. They thereby left the confines of representative democracy themselves. Consequently, the slogan "third Majdan" points to a common denominator - the people intervening and "supervising" politicians or politics as such as soon as they went astray. Given the regional and worldwide distribution of power, only a minority will blame President Porošenko and his government for failing to reverse the loss of Crimea and the bringing the secessionist easternmost provinces back into Kyjiv's fold.

A much larger proportion of the voters all over Ukraine has expressed utter disenchantment and frustration over the domestic track record of the new regime. Rampant corruption, the deterioration in the living standards, and the humiliating territorial losses have belied the promises of new beginnings associated with the radical second Majdan within years. Hence the understanding that all political elites are inherently unreliable and bound to prioritise their own enrichment over the interests of the people they are expected to represent. Consequently, "the people" has to be vigilant and ready to step in every once in a while, without the naïve idealistic belief that its new leaders will be any better. Optimistically, this utter political disenchantment implies the empowerment of civil society as the ultimate judge of democratic legitimacy. This may be a step forward in terms of classic democratic criteria by strengthening civil society. 48 There are, however, obvious risks involved in "the people" or "civil society" eclipsing the representative institutions and elected representatives at will. Yet, no matter how hard they try, "civil society" as a moral force cannot do without leaders, instigators, spokesmen to uphold the illusion of "the people" as a real-existing entity.

Reportedly, Julija Tymošenko urged citizens to instigate a new protest on Kyjiv's central square, pointing at artificially increased utility tariffs and inflation. During a press conference, she accused the president and the head of the National Bank of corruption. In a comment, Kyjiv's main radio station identified the motive behind all Majdans, past and future:

Let's be honest. If we are hypothetically talking about the preparation of the 'third Majdan' or other mass protest actions in one way or another, the Ukrainian people has never come out onto Majdan for economy. It stood up when its political rights and freedoms were trampled down, especially those which have to do with personal dignity, but not the economic ones. If we take a look at 2004, people gathered on Majdan to defend their choice. No matter what, but it was a choice and it was not reckoned with. During the Revolution of Dignity people also did not 
stand up for economic reasons, but because of the political choice concerning the direction of further development for our country. Therefore, Tymošenko and Batkivščyna ['Motherland', her party, OM] will not succeed in igniting mass protests if they only keep relying on economic factors. ${ }^{49}$

Yet, Ukrainian politics too has entered the twenty-first century of fake news, social-media hypes and information bubbles. In parallel to the Ukrainian and western reports on Tymošenko and others threatening to incite a third Majdan, sympathetic Russian reporting on this call caused suspicions. ${ }^{50}$ According to EuromaidanNews, it was Russian media and agents inciting Ukrainians to topple their government once more. Indeed, Russian media and pro-Russian media in eastern Ukraine previously not only vilified the Porošenko administration as illegitimate and outright "fascist," but have also vociferously condemned the first and second Majdan as a violent and treacherous coups d'état orchestrated by Washington and Brussels. All of a sudden, these very same media and their masterminds are applauding and welcoming a third Majdan. They claim that the EU has lost faith in Porošenko and that the Kyjiv regime is isolated and panicky, ready to use violence against the very people that swept them to power a mere three years ago. ${ }^{51}$ In sum, are the people the playmaker here or are they being played? The only certainty remaining in this enactment of disinformation and incitement is that the Majdan will be the theatre.

\section{Bibliography}

Åslund, A., Ukraine. How Ukraine Became a Market Economy and Democracy (Washington DC, 2006).

Anon., "Glava LNR oproverg slova Porošenko o vyborax 'pod dulom avtomatov," NTV, 1 March 2017, [accessed online 19.06.2018: <http://www.ntv.ru/novosti/1258276/. slovaporoshenko-o-tom-chto-vybory-proshli-pod-dul/> ]

Anon., "Sobrat ljudej na Majdan-3 na teme èkonomiki u Timošenko ne vyjdet - èkspert," RIA Novosti Ukraina, 24 November 2016a, [accessed online 19.06.2018: <http:// rian.com .ua/interview/20161124/1018995087.html> ].

Anon., "Majdan pryviv politykiv do vlady I na tomu dlja nyx zakinčyvsja - politolog," UAInfo, 22 November 2016b, [accessed online 19.06.2018: <http://uainfo.org/blog

\footnotetext{
49 Anon. (2016a).

$50 \quad$ Anon. (2016d).

$51 \quad$ Kazanskyi (2015); Anon. (2016d).
} 
news/1479828371-maydan-priviv-politikiv-do-vladi-i-na-tomu-dlya-nih-zakinchiv sya.html > ].

Anon., "Čim buv i čim ne buv Majdan," Novoe Vremja, 21 November 2016c, [accessed online 19.06.2018: <http://nv.ua/ukr/project/story-of-maidan-by-bondar-russ. html $>$.

Anon., “Timošenko pozvala ukraincev na tretij Majdan," Lenta.ru, 14 November 2016d, [accessed online 19.06.2018: <https://lenta.ru/news/2016/11/14/timoshenko/>] .

Anon., "Ghost of Third Maidan," SputnikNews, 11 May 2016e, [accessed online 19.06.2018: $<$ http://sptnkne.ws/dEsX> ].

Anon., "Rekonstrukcija Majdanu može prizvesti do zniščenija istoričnix pam'jatok," Džerkalo tižnja, 5 July 2015, [accessed online 19.06.2018: <http://dt.ua/CULTURE/ rekonstrukciya-maydanu-prizvede-do-znischennya-istorichnih-pam-yatok-177934 -html> ].

Anon., "Janukovič-mladšij: Krym xočet otdelit'sja ot Ukrainy iz-za banderovcev I propovednikov nacisma," Gordon.ua, 16 March 2014a, [accessed online 19.06.2018: <http://gordonua.com/news/politics/yanukovich-mladshiy-krym-hochet-otdelit sya-ot -ukrainy-iz-za-banderovcev-i-propovednikov-nacizma-14081.html> ].

Anon., "Vo vremja vystuplenija Timosjenko Majdan kritsjal 'Ne verim!' I 'Molodets!," Segodnja.ua, 22 February 2014b. [accessed online 26.04.2019: <https://www.segod nya.ua/politics/vo-vremya-vystupleniya-timoshenko-maydan-krichal-ne-verim-imolodec-497991.html > ]

Anon., "Snos pamjatnika Leninu: reakcija v Ukraine i mire," Fakty, 9 December 2013a, [accessed online 19.06.2018: <http://fakty.ua/173445-snos-lenina-reakciya-v-ukraine -i-mire > ].

Anon., “Majdan z ostrogoju sprijnjav zakliki “Timosjenko - president,"” Ukrainski natsionalni novini, 22 February 2014c.

Anon., "Pamjatnik Lenina snesli," Ukrainskaja Pravda, 8 December 2013b, [accessed online 19.06.2018: <https://www.pravda.com.ua/rus/news/2013/12/8/7005453/>].

Anon., “ŠČo uvičnjujut' pam’janiki Kieva?," Tyžden.ua, 4 April 2012, [accessed online 19.06.2018: <http://tyzhden.ua/History/49437> ].

Anon., "Pokrovitelja Kieva trebujut 'otbelit' I 'pereodet," UNIAN, 31 July 2007, [accessed online 19.06.2018: <https://www.unian.net/society/56514-pokrovitelya-kieva-trebu yut-otbelit-i-pereodet.html $>$ ].

Bedritskiy, A., A. Kochetkov, and S. Byshok, Ukraine after Euromaidan. Democracy under Fire (2015).

Beissinger, M.R., "Structure and Example in Modular Political Phenomena. The Diffusion of Bulldozer/Rose/Orange/Tulip Revolutions," in Perspectives on Politics, 5, no. 2 (2007), 259-276. 
Bredies, I., A. Umland, and V. Yakushik, Aspects of the Orange Revolution. IV, Foreign assistance and civic action in the 2004 Ukrainian Presidential Elections (Stuttgart, 2014)

Dahl, R.A., A Preface to Democratic Theory (Chicago, 1956).

Džurkovič, M., “Otpor vnov na Ukraine: Kto oni, psy (nenasilstvennoj) vojny?," Russkaja Obščina, 2 January 2014, [accessed online 19.06.2018: <http://www. russian.kiev.ua/ material.php?id=11608005> ].

Filenko, V., "Vojnu vyigraem, kogda vypolnim trebovanija Majdana," Korrespondent.net, 26 November 2014, [accessed online 19.06.2018: <http://korrespondent.net/ ukraine/ politics/3448237-vladymyr-fylenko-voinu-vyyhraem-kohda-vypolnym-trebovanyiamaidana.

Gerlach, J., Color Revolutions in Eurasia (Heidelberg, 2014).

Hollander, S., The Politics of Referendum Use in European Democracies (New York, 2019). Jowitt, K., "Soviet Neotraditionalism. The Political Corruption of a Leninist Regime," in Soviet Studies 35, no. 3 (1983), 275-297.

Karklins, R., Ethnopolitics and Transition to Democracy: The Collapse of the UssR and Latvia (Baltimore, 1994).

Kazanskyi, D., "The Third Coming? Is Maidan 3.0 possible, and what would it look like?," The Ukrainian Week, 17 December 2015, [accessed online 19.06.2018: <http:// ukrainianweek.com/Politics/154194>].

Kolstø, P., Russians in the Former Soviet Republics (London, 1995).

Kučma, L., Posle Majdana 2005-2006. Zapiski prezidenta (Moscow, 2007).

Kuzio, T., "Ukraine between a Constrained Eu and Assertive Russia," in Journal of Common Market Studies 55 (2016), 103-120.

Kuzio, T., "Political Culture and Democracy" in East European Politics and Societies 25 (2011), 88-113.

Kuzio, T., "Ukraine and the Yugoslav Conflict," in Nationalities Papers 25 (1997), 587600.

Laclau, E., 'Socialism,' the 'People,' 'Democracy'. The Transformation of Hegemonic Logic," in Social Text 7 (1983), 115-119.

Levitsky, S., and L.A. Way, Competitive Authoritarianism: Hybrid Regimes After the Cold War (Cambridge, Mass., 2010).

Lucardie, P., "From Crisis to Democracy. An Exercise in Political Imagination," in J. Gijsenbergh, S.K. Hollander, T. Houwen, and W. de Jong (eds.), Creative Crises of Democracy (Brussels, 2012), 47-6o.

Melvin, N., Russians Beyond Russia. The Politics of National Identity (London, 1995).

Meurs, W. van, "Die Transformation in den baltischen Staaten. Baltische Wirtschaft und russische Diaspora," in Berichte des Bundesinstitut für ostwissenschaftliche und internationale Studien 6 (1999), 1-44.

Negru, N., Twitter Revolution: Episode One Moldova (Chişinău, 2010). 
Nora, P. "Between Memory and History: Les Lieux de Mémoire," in Representations 26 (1989), 7-24.

Onuch, O., "Who Were the Protesters?," in Journal of Democracy 25 (2014), 44-51.

Plokhy, S., "The Ghosts of Pereyaslav: Russo-Ukrainian Historical Debates in the PostSoviet Era," in Europe-Asia Studies 53 (2010), 489-505.

Riabchuk, M., “Ukrainians as Russia's Negative 'Other': History Comes Full Circle," in Communist and Post-Communist Studies 49 (2016), 75-85.

Sakwa, R., Frontline Ukraine: Crisis in the Borderlands (London, 2014).

Samokhvalov, V., "Ukraine Between Russia and the European Union:Triangle Revisited," Europe-Asia Studies 67 (2015), 1371-1393.

Saward, M., The Representative Claim (Oxford, 2010).

Setälä, M-L, Referendums and Democratic Government: Normative Theory and the Analysis of Institutions (Houndmills, 1999).

Sidorčik, A., “Koričnevyj' mjatež na Ukraine," Argumenty i Fakty, January 20, 2014, [accessed online 19.06.2018: <http://www.aif.ru/euromaidan/opinion/korichnevyy_ myatezh_na_ukraine>].

Šmajda, T., "Pomarančeva revoljucija I Evromajdan: vidminnosti, ščo možut' koštuvati peremogi," Textu Analitičnij centr, 25 November 2013, [accessed online 19.06.2018: <http://texty.org.ua/pg/article/editorial/read/49929/Pomarancheva_revolucija_i_ Jevr omajdan_vidminnosti_shho_mozhut $>$ ].

Stepanenko V., and Y. Pylynskyi, Ukraine After the Euromaidan. Challenges and Hopes (Bern, 2015).

Stražnyj O., Mentalitet Majdanu. Xronika podij - svidčennja očevydciv (Kyjiv, 2016).

Thumann, M., "Putins Albtraum: Orange," in Die Zeit 50 (2004), 4-5.

Tilly, C., "Invention, Diffusion, and Transformation of the Social Movement Repertoire," in European Review of History 12, no. 7 (2005), 307-320.

Tolkačov, O., "Pora pomarančevogo Majdanu," Radio Svoboda, 22 November 2009, [accessed online 19.06.2018: <http://www.radiosvoboda.org/a/1884961.html> ].

Tucker, J., "Enough! Electoral Fraud, Collective Action Problems, and Post-Communist Colored Revolutions," in Perspectives on Politics 5, no. 3 (2011), 535-551.

Weber, M, "Politics as a Vocation," in J. Dreijmanis (ed.), Max Weber's Complete Writings on Academic and Political Vocations, (New York, 2008), 155-208.

White, S., and I. McAllister, "Rethinking the "Orange Revolution," in Journal of Communist Studies and Transition Politics 25 (2009), 227-254.

Wittkowsky, A., Fünf Jahre ohne Plan: die Ukraine 1991-96; Nationalstaatsbildung, Wirtschaft und Eliten (Hamburg, 1998).

Zuev, V., "Ukraina i 'Cvetnye revoljucii," Left.ru, 5 January 2009, [accessed online 19.06.2018: <http://left.ru/20og/1/zuev183-2.phtml> ].

Zunneberg, C., and W. van Meurs, "EuroMaidan. Democratie ten top of ten val?," in Donau 1 (2014), 64-69. 